\title{
Commitment in the German Banking and Consulting Industry: Influence of Different Leadership Styles on Employee Commitment
}

\author{
Vinzent Zerner ${ }^{1}$, Eckhard Marten², Jens Brandt ${ }^{3}$
}

Submitted: 16.09.2019. Accepted: 16.08.2021

\section{Abstract}

Purpose: The success of a firm often largely depends on its employees. Therefore, we propose and test the possibility of influencing affective and normative commitment by transactional, transformational, and passive leadership styles.

Implications: Demographic change is progressing slowly but steadily; here lies the crucial point. Our results show that only transformational leadership influences the commitment dimensions positively. That can help make the best use of scarce human resources to remain competitive in the long term.

Originality/Value: The article provides new information concerning the relationship between transformational and transactional leadership style and their influence on commitment within the banking and consulting sector of the German service industry. It highlights the need for further research into this topic across industries and demographics. For cross-cultural (USA-Germany) comparisons, the article might help to understand differences and trends within globalization.

Methodology: To address this question, we conducted interviews with 197 employees of the financial service sector in Germany to confirm the relationship between leadership styles and employee commitment. In order to verify and extend previous research, we planned an explanatory study. We used the multiple regression analysis to examine this relationship.

Findings: The results provide new evidence for German participants, which show (1) that transformational leadership is the "optimum" to facilitate commitment and is completely decoupled from the other leadership styles. (2) Preliminary studies revealed a preference toward transactional leadership, which correlated positively with affective and normative commitment. The present study cannot confirm this correlation. (3) Passive leadership correlates negatively with commitment, which indicates that the avoidance of passive leadership is essential. In sum, the correlation for different leadership styles (except transactional leadership style) is higher than in the preliminary studies. This indicates that the relationship between leadership styles and affective and normative commitment is exceeding the assumptions.

Keywords: leadership, commitment, demographic change, banking, consulting.

JEL: M12, M54

\footnotetext{
Zeppelin University, Am Seemooser Horn 20, 88045 Friedrichshafen, Germany; e-mail: v.zerner@zeppelin-university.net.

2 Corresponding author, International School of Management, Mörfelder Landstraße 55, 60598 Frankfurt am Main, Germany; e-mail: Eckhard. Marten@ism.de; https://orcid.org/0000-0002-2865-5047.

3 International School of Management, Mörfelder Landstraße 55, 60598 Frankfurt am Main, Germany; e-mail: jens.brandt@ism.de.
} 


\section{Introduction}

Today, it is more important than ever for companies to compete for skilled specialists and executives. Globalization, digitalization, and demographic changes are just a few of the influencing factors. The currently hired employees often belong to Generation Y. This group of young, well-trained people is accustomed to having numerous options for just about everything, both in their private and professional lives (Sainger, 2018). This shows a new and challenging aspect for their employers, especially in terms of leadership (Tavakkoli, 2009). Moreover, due to globalization and digitalization, management roles change along with business processes that constantly evolve: by utilizing modern technology to create new processes (or modify existing ones), resulting in a continually accelerating pressure to adapt (Ademola, 2016).

In this context, commitment is extremely valuable. It describes every employee's attachment to the company. This bond supports both the reduction of employee turnover and the increase of employee motivation to provide outstanding services for the company (Westphal and Gmür, 2009). According to Moser (1997), commitment describes an action. A committed person shows a relatively stable behavior over a long period and consciously rejects alternatives, such as other job offers (Asif et al., 2019).

In recent decades, transformational leadership is one of the most important leadership concepts, and there is growing interest in how such a leadership style impacts employee commitment. Consequently, we consider transformational leadership (Bass, 1985) to be an appropriate starting point for this study.

However, it is of practical importance to better understand the impact of leadership on "young professionals." Gulluce et al. (2016) already studied the banking industry in this light, but only with a general sample. In the long term, companies can only succeed in recruiting desirable candidates if they communicate their employee orientation to the outside world and pursue it based on an overall system of leadership, values, and vision, but also personnel tools (Tavakkoli, 2009, p. 32).

This study offers first insights into how to lead and engage the next generation of employees in the banking and consulting sector. Once qualified employees have been recruited, they must be integrated into the corporate context. The direct superior plays a big role in an employee's integration into the company (Schuhmacher and Geschwill, 2014). Furthermore, the management or leadership style significantly impacts employee turnover (Sprenger and Novotny, 2016). In short, this article gives a concrete guide on how to motivate Generation Y, based on the literature review and own study findings. 
As a result, our conclusions will support companies in navigating through the challenging times in which human capital becomes increasingly important.

\section{Theoretical Background and Prior Research}

In Germany, the influence of leadership styles on commitment was already demonstrated by Felfe (2005). His model and empirical studies have so far been strongly normative to the effect that a specific management style - the "transformational" style - is the "best leadership style" to be pursued. According to the situational leadership models introduced by Hersey and Blanchard (1969), we should differentiate that neither can single employee groups (e.g. "industrial workers," "emotional workers," etc.) nor "employees" themselves say that one style of leadership always leads to the best outcome (Graeff, 1983; Asif et al., 2019).

Among others, Buil et al. (2019) show that commitment has an influence on various factors, such as employee performance and company stock prices fluctuation rate. We will investigate in more detail, how it can be increased by executives through leadership (Lapointe and Vandenberghe, 2018; Buil et al., 2019; Farahnak et al., 2020). The study aims to confirm both aspects mentioned above. Moreover, there are further findings from the literature regarding employees working at consultancies and banks. The aim is to verify or falsify additional hypotheses derived from the theoretical part. Lastly, we will examine in more detail the less mentioned sub-areas like positive moderator effects between different management styles and their consequences for the commitment.

\section{Organizational Commitment}

According to Mathieu and Zajac, organizational commitment (OC) can be defined as "a bond or linking of the individual to the organization" (Mathieu and Zajac, 1990, p. 171), with consideration of fundamental ideas (e.g. Becker, 1960; Salancik, 1977; Mowday, Porter, and Steers, 1982). Moser et al. (2014) argue that all approaches differ only in how this bond to the company was made.

In this article, OC represents the dependent variable. The article aims to examine and improve the comprehensibility of the factors that influence OC. Subsequently, we will investigate different leadership styles as influencing factors in the next section.

Commitment to the company is divided into three dimensions: (1) affective commitment, which describes an emotional linking; (2) continuance commitment, which 
refers to weighing up alternatives; and (3) normative commitment, which contains the obligation to the company, e.g. due to corresponding socialization (Jaros, 2007; Gulluce et al., 2016).

Meyer and Allen (1991) and recently Gulluce et al. (2016) show that the three dimensions correlate with one another to a different extent. There is a very weak correlation between continuance and affective commitment and between continuance and normative commitment, not to mention the study by Meyer and Allen (1991) even shows negative correlations. However, affective and normative commitment show a positive correlation (Meyer and Allen, 1991).

The sample examined in the present study focused on whether leadership directly causes affective and normative commitment (Mowday et al., 1979). Therefore, these two dimensions of commitment were used for the following survey. The continuance commitment is based on a rational cost-benefit analysis, which in turn allows for a wide range of influencing factors that can be excluded in this case (Moser, 1997).

We also included in our investigation the more recent studies, such as the one by Solinger, van Olffen, and Roe (2008). However, the three-dimensional model by Meyer and Allen (1991) is best suited for the present study as it provides statistical results from the past (both for Germany and the USA), thus allowing for a comparison with previous studies.

Factors Influencing the OC. The work-related factors that influence OC refer to work situation characteristics: relationship to superiors, corporate culture, connection to colleagues, and type of work activity (Moser, 1997). The organization-related factors that influence OC refer to the corporate structure determined by the company's management and the methods of human resource management, such as communication structure, induction, further training measures, and career opportunities (Mowday et al., 1982).

Result Factors of OC. "Commitment plays an important role in predicting behaviour at the workplace. As many literature reviews have shown, commitment correlates with work outcomes" (Riketta and Dick, 2009, p. 69). Increased commitment appears when the employee remains loyal to the company even in difficult times; hence, employee turnover decreases, and employees take fewer sick days (Westphal and Gmür, 2009). Work performance means that the employee is willing to perform extra work and advocates for the well-being of other employees (Mowday et al., 1979). Health and well-being were subsequently observed by Meyer et al. (2002) in reference to employee health issues such as burnout. 


\section{Trends within Globalization}

Globalization combines many interconnected, far-reaching, and complex factors: economic, political, sociocultural, demographic, linguistic, technological, and environmental. These factors impact leadership paradigms and the societies in which they operate. The positive effects of globalization include economic growth, technological advancement, political and social integration, while the negative results include feelings of disenfranchisement, injustice, hostility, and exclusion. Therefore, leaders must not only be able to keep up with the critical and multifaceted global trends that impact everything they do, but they should also be flexible and able to adapt to the ebb and flow of the ever-changing forces of globalization in the twenty-first century (Litz, 2011). Huber (2004) suggests that a transformational leader is more engaged with the people performing the tasks, forging relationships, making a conscious effort to gain cooperation and commitment, and actively influencing organizational culture. Achieving collaboration with, engagement in, and active influence on company culture leads to more cooperation, coherence, and independent teaching and learning of employees (Huber, 2004). This might be one of the important factors that form the challenges arising from globalization.

\section{Employee OC in Management Consulting and Banking}

The present study concentrates on employees in the consulting and banking industries as its value is strongly linked to its employees' knowledge and networks (Donnelly, 2006). Thus, in these sectors, it is of great importance to avoid the exchange of knowledge and know-how with competitors as this can result in enormous economic damage for companies (Haller, 2015). Since new entrants generally have a higher turnover rate, the proportion of this group of employees was deliberately kept high at around $60 \%$ of the survey group. Moreover, knowledge management and free knowledge flow within the company are especially important for the consulting and banking industry, and they can be facilitated by appropriate leadership (Kumar, 2008).

\section{Leadership as a Possible Cause for Affective and Normative Commitment}

To be more precise with leadership - as part of work characteristics - and the possible extent of its influence on affective and normative commitment, we specified leadership styles. Therefore, an integrating model of leadership styles - namely the Full Range of Leadership Model (FRLM) - was used to establish the context of leadership as a possible cause for affective and normative commitment. 
Full Range of Leadership Model. The FRLM counts among the new leadership approaches. According to the definition, the FRLM offers a complete range of leadership. By using the "Multifactor Leadership Questionnaire 5x" (MLQ) that considers various influencing factors - personality, influence, situational variables, and result variables - the different dimensions are measurable (Felfe and Goihl, 2002b). The original model (Burns, 1978) with its transactional and transformational concept was translated by Bass (1985) from politics to business. Since this article considers the construct of leadership and its impact on commitment, Bass's construct appears as most suitable for our needs (Nerdinger, 2019). The FRLM represents a holistic approach to leadership and enables the investigator to make a clear statement about which leadership style positively influences commitment. There is no need to limitate any concept, which increases the general validity of the examination. Moreover, this part ensures that the recommended action is relevant for companies that consider as many management approaches as possible.

Transformational Leadership Style. The transformational leadership style describes how the transformation of values and attitudes results in increased performance, namely eschewing selfish and individual goals for the sake of long-term overarching corporate goals. In this style, the manager seeks to influence the intrinsic motivation of his employees. Bass et al. (2003) enumerate four dimensions: idealized influence/ charisma, inspiring motivation, intellectual stimulation, and individual employee orientation (Farahnak et al., 2020). In this study, the hypotheses were derived from existing research in this area to provide empirical evidence. It was an "ex post facto design" as the preconditions for quasi-experimental and experimental investigations were not given. Because previous studies (e.g. Bass et al., 2003; Farahnak et al., 2020; Felfe, 2006) and commitment management studies indicate that transformational leadership and its effects on employees positively influence commitment, we expected that it positively affects the commitment of employees in consulting and banking.

Hypothesis 1a: Transformational leadership is positively related to affective commitment.

Hypothesis 2a: Transformational leadership is positively related to normative commitment.

Transactional Leadership Style. The transactional leadership style describes an interdependence between employees and managers. Transactional management focuses on managers following their employees' individual goals like salary to satisfy them, thus raising employee goals to a higher level. Two categories determine the transactional management style: conditional reward and active management by exception (Bass et 
al., 2003). Felfe (2006) confirmed that transactional leadership positively influences German employees. Therefore, we expect a positive correlation between leadership and commitment.

Hypothesis 1b: Transactional leadership is positively related to affective commitment.

Hypothesis $2 b$ : Transactional leadership is positively related to normative commitment.

Passive Leadership Style. Since passive managers avoid influencing their employees, this leadership style is also known as "non-leading." The two components that determine this kind of leadership are passive management by exception and laissez-faire (Bass et al., 2003). Because previous studies (e.g. Bass et al., 2003; Felfe and Goihl, 2002b; Felfe, 2006) show that both dimensions of passive leadership have a negative impact on commitment, we expect that the leadership style negatively relates to affective and normative commitment.

Hypothesis 1c: Passive leadership is negatively related to affective commitment. Hypothesis 2c: Passive leadership is negatively related to normative commitment.

According to Bass (1985), transformational leadership promotes employee performance beyond the effect of transactional leadership (augmentation effect). We postulated above that transactional leadership style is positively correlated with affective commitment and transformational leadership moderates this relation in a positive way. Because we assumed that the transformational leadership style correlates more positively with affective commitment than the transactional leadership style, we may consider a positive moderator effect. In other words, the level of the transformational leadership style influences the effect of the transactional leadership style on affective and normative commitment.

Hypothesis 3a: Transformational leadership positively moderates the relationship between transactional leadership and affective commitment. The affective commitment rises with the increase in transformational leadership.

Hypothesis 3b: Transformational leadership has a positive moderator effect on the relationship between transactional leadership and normative commitment. The normative commitment rises with the increase in transformational leadership. 


\section{Methods}

\section{Procedure}

The study was conducted using an online survey via sosci-survey.de. Participants were recruited through the authors' network in the financial and consulting sectors; the companies were asked to distribute the survey to their employees. Furthermore, we questioned graduates who started working in the last two years and undergraduates currently pursuing internships in the relevant industries. Since commitment primarily originates from the first two years of employment, this group was essential (Klaffke and Parment, 2011). Before the evaluation, the data set was cleaned. Incomplete data was removed, as was data from participants who were unemployed or in an internship at the time of the survey or who were self-employed and thus had no manager. Statistical analysis was performed using SPSS software, and multiple regression analyses were used to test the hypotheses, with moderation analysis as hierarchical regression. Furthermore, this study employed an "ex-post facto design" as neither the prerequisites for quasi-experimental or experimental design were provided (Raab-Steiner and Benesch, 2012).

\section{Participants}

The final sample size was $\mathrm{N}=197$. Only employees from the consulting and banking sectors were surveyed. Among the participants, 106 (53.8\%) were men, and 91 (46.2\%) - women. For data protection reasons, age was recorded in categories to make the data traceable. Participants 30 years old or younger comprised $58.9 \%$ of the survey group, $24.4 \%$ were between 31 and 40 years old, 11.2\% were between 41 and 50 years old, and $5.1 \%$ were over 50 years old. One participant did not provide the age. For statistical analysis, participants were divided into two age groups: the group of younger participants (up to 30 years) represented $58.4 \%(\mathrm{~N}=115)$ of the sample, the group of older participants (over 30 years) comprised $41.1 \%(\mathrm{~N}=81)$ of the sample. Employed participants formed $80.2 \%(\mathrm{~N}=158)$ of the surveyed group, and $19.8 \%(\mathrm{~N}=39)$ were completing an internship. The duration of employment at the current firm was distributed in the sample as follows: $26.4 \%$ had been employed for less than one year, $47.7 \%$ for up to five years, $19.8 \%$ for five to 10 years, and $6.1 \%$ for more than 10 years.

\section{Measures}

Questionnaires were administered in German, using well-validated scales in German. Both questionnaires use a five-point scale, from 1 (never) to 5 (almost ever). 
Transactional and transformational leadership were measured with MLQ according to Felfe and Goihl (2002b). To calculate the scale score for transactional leadership, we used the seven items of the two subscales: contingent reward; active management by exception. To calculate the scale score for transformational leadership, we used five subscales: intellectual stimulation; inspirational motivation; idealized influence attributed; idealized influence behavior; and individual consideration. Jointly, they comprise 20 items.

To measure organizational commitment, we employed the German translation of the affective commitment scale and the normative commitment scale by Schmidt, Hollmann, and Sodenkamp (1998). Since the results of the pre-test recommended shortening, each dimension of the questionnaire contained eight items.

\section{Results}

First, we examined the descriptive statistics, intercorrelations, and reliabilities (Table 1). Affective commitment correlated with $r=.575$ to transformational leadership, thus clearly showing the influence on affective commitment. Passive management correlated negatively with affective commitment. All figures correlated with $\mathrm{r}<-.389$, which suggested a medium-strong negative correlation and was on average $r=-.100$ more negative than Felfe's (2006a) figures.

Table 1. Descriptive statistics

\begin{tabular}{|c|c|c|c|c|c|c|c|c|c|}
\hline & MEAN & SDV & gender & age & $\begin{array}{c}\text { transf. } \\
\text { L. }\end{array}$ & $\begin{array}{c}\text { transa. } \\
\text { L. }\end{array}$ & $\begin{array}{c}\text { passive } \\
\mathrm{L} .\end{array}$ & aC & $\mathrm{nC}$ \\
\hline gender & .46 & .50 & & & & & & & \\
\hline Age & .41 & .49 & $.02^{* *}$ & & & & & & \\
\hline transformational L. & 3.70 & .64 & $-.16^{* *}$ & $.01^{* *}$ & $(.90)$ & & & & \\
\hline transactional L. & 3.28 & .45 & $.07^{* *}$ & $-.08^{* *}$ & $34^{* *}$ & $(.47)$ & & & \\
\hline passive $\mathrm{L}$. & 2.27 & .60 & $.09^{* \star}$ & $-.04^{* *}$ & $-.58^{* *}$ & $-.39^{* *}$ & (.53) & & \\
\hline affective $\mathrm{C}$. & 3.76 & .69 & $-.05^{* *}$ & $.01^{* *}$ & $.56^{\star \star}$ & $.14^{\star \star}$ & $-.39^{* \star}$ & $(.72)$ & \\
\hline normative $\mathrm{C}$. & 3.42 & .70 & $.09^{\star *}$ & $.06^{* *}$ & $.35^{* *}$ & $.11^{\star \star}$ & $-.26^{\star *}$ & $.54^{* \star}$ & $(.71)$ \\
\hline
\end{tabular}

Note: $\mathrm{N}=197$; Reliability (Cronbachs Alpha) in Brackets; ${ }^{*} \mathrm{p} \leq .05$; ${ }^{* *} \mathrm{p} \leq .01$; gender: $0=$ male; $1=$ female; age: $0=$ up to 30 years; $1=$ over 30 years.

Source: own elaboration. 
The two main personal characteristics - gender and age - emerged as uncorrelated in all three leadership styles and both dimensions of commitment.

All leaderships styles were correlated, while affective and normative commitment were correlated, too. Transformational leadership was significantly positively correlated with commitment, and passive leadership was significantly negatively correlated with commitment. Only transactional leaderships correlated with commitment on a low level.

Table 2 shows the result of regression analysis to explain affective and normative commitment by leadership.

Table 2. Regression analysis affective and normative commitment by leadership

\begin{tabular}{|c|c|c|c|c|c|}
\hline \multirow{2}{*}{ Step } & \multirow{2}{*}{ Predictors } & \multicolumn{2}{|c|}{ affective commitment } & \multicolumn{2}{|c|}{ normative commitment } \\
\hline & & Beta & $\Delta \mathrm{R}^{2}$ & Beta & $\Delta \mathbf{R}^{2}$ \\
\hline 1 & $\begin{array}{l}\text { gender } \\
\text { age }\end{array}$ & $\begin{array}{l}-.052^{\star * \star} \\
.009^{\star * *}\end{array}$ & $.003^{* * *}$ & $\begin{array}{l}-.089^{\star * *} \\
.057^{* * *}\end{array}$ & $.011^{* * *}$ \\
\hline 2 & $\begin{array}{l}\text { transformational } \\
\text { transactional } \\
\text { passive }\end{array}$ & $\begin{array}{l}.553^{\star \star *} \\
-.090^{\star \star *} \\
-.107^{\star \star \star}\end{array}$ & $.341^{\star \star \star}$ & $\begin{array}{l}.300^{* * *} \\
-.020^{\star * *} \\
-.085^{\star * *}\end{array}$ & $.119^{\star * *}$ \\
\hline
\end{tabular}

Note: $\mathrm{N}=197 ;{ }^{* *} \mathrm{p}<.01,{ }^{* *} \mathrm{p}<.001$; gender: $0=$ male; $1=$ female; age: $0=$ up to 30 years; $1=$ over 30 years. Source: own elaboration.

After excluding the impact of gender and age (both were dummy coded with 0 and 1), the $34 \%$ variance of affective commitment was explained by the three leadership styles, but only transformational leadership had a significant effect. Because of this result, we could have confirmed hypothesis 1a but not hypotheses $1 \mathrm{~b}$ and 1c. The three leadership styles showed a $12 \%$ variance of normative commitment. After control, it turned out to be the influence of gender and age. Thus, hypothesis 2a was confirmed, while hypotheses $2 \mathrm{~b}$ and $2 \mathrm{c}$ were rejected. Although the variance resolution is lower for $\mathrm{H} 2$ than for $\mathrm{H} 1$, the pattern is the same: transformational leadership influences the commitment dimensions; the other two styles have no effect. 
Table 3 shows the hierarchical regression analysis result to test the moderation effect of transformational leadership on the relationship between transactional leadership and commitment.

Table 3. Results from hierarchical regression analysis predicting affective and normative commitment

\begin{tabular}{|c|c|c|c|c|c|}
\hline \multirow{2}{*}{ Step } & \multirow{2}{*}{ Predictors } & \multicolumn{2}{|c|}{ affective commitment } & \multicolumn{2}{|c|}{ normative commitment } \\
\hline & & BETA & $\Delta \mathrm{R}^{2}$ & BETA & $\Delta \mathrm{R}^{2}$ \\
\hline 1 & $\begin{array}{l}\text { gender } \\
\text { age }\end{array}$ & $\begin{array}{l}-.052^{* * *} \\
.009^{\star * *}\end{array}$ & $.003^{\star * \star}$ & $\begin{array}{c}-.089^{* * *} \\
.057^{* * *}\end{array}$ & $.011^{* * *}$ \\
\hline 2 & $\begin{array}{l}\text { transactional } \\
\text { transformational }\end{array}$ & $\begin{array}{l}-.066^{* * *} \\
.606^{\star * *}\end{array}$ & $.334^{* * *}$ & $\begin{array}{l}-.001^{* * *} \\
.343^{* * *}\end{array}$ & $.114^{\star \star \star}$ \\
\hline 3 & Interaction & $-.084^{\star * *}$ & $.007^{* \star *}$ & $-.099^{* * *}$ & $.010^{\star \star \star}$ \\
\hline
\end{tabular}

Note: $\mathrm{N}=197 ;{ }^{* *} \mathrm{p}<.01,{ }^{* *} \mathrm{p}<.001$; gender: $0=$ male; $1=$ female; age: $0=$ up to 30 years; $1=$ over 30 years. Source: own elaboration.

The analyses showed that the interaction term was not significant. Therefore, hypotheses $3 \mathrm{a}$ and $3 \mathrm{~b}$ were not supported.

\section{Discussion}

The study could not confirm whether prior research (Felfe and Goihl, 2002b; Felfe, 2006) identifies the preferred leadership style for employees in the consulting and banking sectors. In conclusion, only transformational leadership leads to success in these sectors.

Thus, we may assume that there is a correlation between transformational leadership and affective commitment among employees of banks and consultancy agencies. This result is higher than Felfe's results (2006a). We may deduce that the transformational leadership style has a more significant influence on the affective commitment of our respondents than the one shown in Felfe's study (2006b). According to our study, the 
transformational leadership style's impact on the development of affective commitment is even higher than already assumed. One reason for this could be the age of $59 \%$ of the interviewees ranging from 20 to 30 years, while $25 \%$ were between 30 and 40 , and $11 \%$ were between 40 and 50 (the rest was older). According to preliminary studies, this age group is of great importance to high-quality leadership (Klaffke and Parment, 2011). Furthermore, a significant reason for this could be that the respondents come from banking and consulting, representing customer contact employees. The influence of "emotional" leadership is substantial here (Nerdinger and Pundt, 2018). The effect of transformational leadership on respondents' emotions is further directly supported by empirical studies (Bono et al., 2007), which adequately explains the strong tendency toward transformational leadership.

Therefore, the regression analysis delivers valuable insights to explain affective commitment by leadership. The three leadership styles can explain 34\% variance of affective commitment, but only transformational leadership shows a significant effect. This underlines the finding that the positive impact of transformational leadership is detached from transactional leadership; thus, hypothesis 1a can be confirmed while hypotheses $1 \mathrm{~b}$ and $1 \mathrm{c}$ are not supported.

The result of the exemplary leadership described in this article has enhanced the theoretical assumptions. We assumed that the interviewed Germans would desire a different leadership than US-Americans, a population in which the $\mathrm{MbEa}$ (part of transactional leadership) scale is much higher. Among US respondents, a drop on the CR scale is typical, as shown in Felfe's (2006a) study. Therefore, for the employees surveyed in our study, the most efficient leadership style is similar to the leadership in the USA.

Due to these results, it is even more important to avoid passive leadership than to lead in a transactional style (Felfe, 2006a).

In conclusion, the results of affective and normative commitments are similar. The leadership styles correlate with $\mathrm{r}=.150$ on average, namely stronger with affective than normative commitment. What is particularly interesting is that the transactional leadership style has no significant influence, but the CR scale retains great importance. Therefore, the assumed preferred German leadership style could not be confirmed. Moreover, the most efficient leadership described has similar characteristics to those of Bass (1995).

On the one hand, this deviation from the expectation can be ascribed to the consulting and banking sectors and their high degree of interlacing with US-American com- 
panies. On the other hand, the respondents' age is likely to play a significant role: about half of the respondents were 20 to 30 years old (Klaffke and Parment, 2011); $19.8 \%$ of them pursued an internship and just started their career, emphasizing the importance of good leadership for career starters.

Since the USA often shapes modern leadership styles, we may assume that the link between the younger generations and the American ideal leadership style is higher than the interlacing with the older generation (Hilger, 2004). This process of Americanization is intensified by globalization (Otte, 2006). Furthermore, what increasingly gains importance is networking with American companies, especially in the consulting and banking sector. Today, it is very common to work in international teams. Moreover, the exchange between employees is explicitly promoted in consultancies and banks, which could further impact these deviating results.

Subsequently, we examined whether transactional leadership has a positive moderator effect. Since transactional leadership did not correlate significantly with the two dependent variables, the possibility of a significant positive moderator effect was questionable from the outset. The hypotheses in this part were also rejected in favor of the null hypothesis. In its definite form, transactional leadership has a slightly negative effect on both commitment dimensions.

Overall, these results clarify that the transformational leadership style is mainly independent of other leadership styles' interaction effects. Moreover, the mere existence of this type of leadership style positively contributes to the affective and normative commitment of employees in the consulting and banking sector.

\section{Summary}

The analysis of previous studies (Felfe and Goihl, 2002a; Felfe, 2006a; Felfe, 2006b) revealed that transactional leadership tends to be more desirable and correlates positively with affective and normative commitment. This statement could not be confirmed in our study. Furthermore, the assumption that the transactional leadership style positively moderates transformative leadership could not be verified (Bass, 1985; Podsakoff, MacKenzie, Moorman, and Fetter, 1990; Podsakoff, MacKenzie, and Bommer, 1996; Felfe, 2006a).

While the transformational leadership style correlates positively with the surveyed employees' affective and normative commitment, the passive leadership style has a negative 
effect. As a result, the transformational leadership style is the most suitable management style to develop commitment. Therefore, the transformational leadership style positively influences commitment and is not influenced by other management styles.

As highlighted in the theory, it is of great importance to avoid the exchange of knowledge and know-how with competition while still enabling free knowledge flow within the company. Kumar (2008) proved that for knowledge workers in India. Our article shows that transformational leadership supports the following three success criteria: (1) avoiding the exchange of knowledge with competitors; (2) reducing turnover rate; and (3) enabling free knowledge flow within the company.

\section{Theoretical Implications}

The results show that the topic is highly relevant and should be addressed in future research. The decisive factor is likely to be the demographic change having a constant and inexorable impact. The demographic shift is increasingly forcing companies to implement measures to optimally utilize scarce human resources to maintain competitiveness (Ballwieser, 2007). Since transformational leadership has turned out to be decisive for the affective and normative commitment of career starters and the associated result factors, companies should be guided by this kind of leadership. Future studies should focus on the younger generation and the influence of leadership on the core success drivers defined in theory, thus reducing fluctuation and enhancing knowledge flow within the company.

\section{Practical Implications}

Future-oriented companies with the desire to be competitive and innovative through the creative skills and ability of young employees are advised to train their managers in transformational leadership.

Sosik and Jung (2010) describe that transformational leadership could be conveyed with training methods. Bass (1985) already indicated that we can develop a transactional leader into a transformational one by using the right combination of training and subsequent $360^{\circ}$ feedbacks (Bass, 1999).

Transformational leadership could currently be described as "the optimal leadership," which serves as a significant benchmark for companies and managers. Our results 
show that only transformational leadership has an impact on commitment dimensions. Leading with emotions in banking and consulting is particularly important since they are service industries (Buil et al., 2019), which is why transformational leadership is indispensable. The techniques especially crucial for leaders are: (1) idealized influence that explicitly targets the pride and respect that employees experience; (2) inspirational motivation that emphasizes evoking enthusiasm and optimism in employees; (3) individualized treatment reinforces the positive emotions triggered by the employee by addressing his or her needs. In short, leadership helps to achieve overall company goals by stimulating central drivers for success.

\section{Limitations}

This article considers the affective and normative commitment components, focusing on the independent variable of leadership. A study of other foci was not included. Nevertheless, such a study could help researchers to elaborate on the importance of leadership in further investigations. Our study only considered the influencing factor of leadership. An extension of possible independent variables in the area presented in this article can further highlight the significance of leadership in contrast to other influencing variables, such as job characteristics. After all, the revealed reliabilities of both transactional and passive management were low $(<.6)$, which should future studies in the field should take into consideration.

\section{References}

Ademola, E.O. (2016). Shifting management and leadership roles in a digital age: An analysis. Journal of Digital Innovations \& Contemporary Research in Science and Engineering, 4(4), 13-18. https://doi.org/10.22624/AIMS/D/V4N4P2.

Armstrong, M. (2010). Armstrong's essential human resource management practice: A guide to people management. London: Kogan Page.

Asif, M., Qing, M., Hwang, J., and Shi, H. (2019). Ethical leadership, affective commitment, work engagement, and creativity: Testing a multiple mediation approach. Sustainability, 11(16), 4489. https://doi.org/10.3390/su11164489.

Bass, B.M. (1985). Leadership and performance beyond expectations. New York: Free Press.

Bass, B.M. (1999). Two decades of research and development in transformational leadership. European Journal of Work \& Organizational Psychology, 8, 9-32. https://doi.org/10.1080/135943299398410.

Bass, B.M., and Avolio, B.J. (1990). Transformational leadership development: Manual for the Multifactor Leadership Questionnaire. Palo Alto, CA: Consulting Psychologists Press.

Bass, B.M., and Avolio, B.J. (1994). Introduction. In: B.M. Bass and B.J. Avolio (eds.), Improving organizational effectiveness through transformational leadership: 1-9. Thousand Oaks, CA: Sage. 
Bass, B.M., and Avolio, B.J. (1995). MLQ Multifactor Leadership Questionnaire. Redwood City, CA: Mind Garden. https://doi.org/10.1037/t03624-000.

Bass, B.M., Avolio, B.J., Jung, D.I., and Berson, Y. (2003). Predicting unit performance by assessing transformational and transactional leadership. Journal of Applied Psychology, 88, 207-218. https://doi.org/10.1037/0021-9010.88.2.207.

Becker, H.S. (1960). Notes on the concept of commitment. American Journal of Sociology, 66, 32-40. https://doi.org/10.1086/222820.

Bierhoff, H.-W. (2006). Sozialpsychologie: Ein Lehrbuch (6th ed). Stuttgart: Kohlhammer.

Bono, J.E., Foldes, H.J., Vinson, G., and Muros, J.P. (2007). Workplace emotions: The role of supervision and leadership. Journal of Applied Psychology, 92, 1357-1367. https://doi.org/10.1037/0021-9010.92.5.1357.

Brodbeck, F.C., Frese, M., and Javidan, M. (2002). Leadership made in Germany: Low on compassion, high on performance. Academy of Management Executive, 16(1), 16-29. https://doi.org/10.5465/ame.2002.6640111.

Brückner-Bozetti, P. (2015). Unternehmensberatung und Partizipation: Eine empirische Untersuchung in Krankenhausunternehmen. Wiesbaden: Springer Gabler. https://doi.org/10.1007/978-3-658-10032-2.

Buil, I., Martínez, E., and Matute, J. (2019). Transformational leadership and employee performance: The role of identification, engagement and proactive personality. International Journal of Hospitality Management, 77, 64-75. https://doi.org/10.1016/j.ijhm.2018.06.014.

Burns, J.M. (1978). Leadership. New York: Harper \& Row.

Bushra, F., Usman, A., and Naveed, A. (2011). Effect of transformational leadership on employees' job satisfaction and organizational commitment in banking sector of Lahore (Pakistan). International Journal of Business and Social Science, 2, 261-267.

Caruana, A., and Calleya, P. (1998). The effect of internal marketing on organizational commitment among retail bank managers. International Journal of Bank Marketing, 16, 108-116. https://doi. org/10.1108/02652329810213510.

Donnelly, R. (2006). How "free" is the free worker? An investigation into the working arrangements available to knowledge workers. Personnel Review, 35, 78-97. https://doi.org/10.1108/00483480610636803.

Farahnak, L.R., Ehrhart, M.G., Torres, E.M., and Aarons, G.A. (2020). The influence of transformational leadership and leader attitudes on subordinate attitudes and implementation success. Journal of Leadership \& Organizational Studies, 27, 98-111. https://doi.org/10.1177/1548051818824529.

Felfe, J. (2005). Charisma, transformationale Führung und Commitment. Köln: KSV, Kölner Studien-Verl.

Felfe, J. (2006a). Transformationale und charismatische Führung - Stand der Forschung und aktuelle Entwicklungen. Zeitschrift für Personalpsychologie, 5, 163-176. https://doi.org/10.1026/1617-6391.5.4.163.

Felfe, J. (2006b). Validierung einer deutschen Version des "Multifactor Leadership Questionnaire" (MLQ Form 5 x Short) von Bass und Avolio (1995). Zeitschrift für Arbeits- und Organisationspsychologie, 50, 61-78. https://doi.org/10.1026/0932-4089.50.2.61.

Felfe, J. (2014). Transformationale Führung: Neue Entwicklungen. In: J. Felfe (ed.), Trends der psychologischen Führungsforschung: Neue Konzepte, Methoden und Erkenntnisse, 39-53. Göttingen: Hogrefe.

Felfe, J., and Goihl, K. (2002a). Transformational leadership and commitment. In: J. Felfe (ed.), Organizational development and leadership, 87-124. Frankfurt am Main: Lang. 
Felfe, J., and Goihl, K. (2002b). Deutsche überarbeitete und ergänzte Version des «Multifactor Leadership Questionnaire». In: A. Glöckner-Rist (ed.), ZUMA-Informationssystem. Elektronisches Handbuch sozialwissenschaftlicher Erhebungsinstrumente (Version 5.00). Mannheim: ZUMA.

Graeff, C.L. (1983). The situational leadership theory: A critical view. Academy of Management Review, 8, 285-291. https://doi.org/10.5465/amr.1983.4284738.

Gulluce, A.Ç., Kaygin, E., Kafadar, S.B., and Atay, M. (2016). The relationship between transformational leadership and organizational commitment: A study on the bank employees. Journal of Service Science and Management, 9, 263-275. https://doi.org/10.4236/jssm.2016.93033.

Haller, S. (2015). Dienstleistungsmanagement: Grundlagen - Konzepte - Instrumente (6th ed.). Wiesbaden: Springer Gabler.

Hersey, P., and Blanchard, K.H. (1969). Life cycle theory of leadership. Training \& Development Journal, 23(5), 26-34.

Hilger, S. (2004). Amerikanisierung» deutscher Unternehmen: Wettbewerbsstrategien und Unternehmenspolitik bei Henkel, Siemens und Daimler-Benz (1945/49-1975). Stuttgart: Steiner.

Huber, S. (2004). School leadership and leadership development: Adjusting leadership theories and development programs to values and core purposes of school. Journal of Educational Administration, 42(6), 669-684. https://doi.org/10.1108/09578230410563665.

Jaros, S. (2007). Meyer and Allen model of organizational commitment: Measurement issues. The ICFAI Journal of Organizational Behavior, 6(4), 7-25.

Klaffke, M., and Parment, A. (2011). Herausforderungen und Handlungsansätze für das Personalmanagement von Millennials. In: M. Klaffke (ed.), Personalmanagement von Millennials: Konzepte, Instrumente und Best-Practice-Ansätze. Wiesbaden: Springer. https://doi.org/10.1007/978-3-8349-6964-4_1.

Koh, C. (2015). Motivation, leadership and curriculum design. Singapore: Springer. https://doi.org/10.1007/978-981-287-230-2.

Kuchinke, K.P. (1999). Leadership and culture: Workrelated values and leadership styles among one company's US and German telecommunication employees. Human Resource Development Quarterly, 10, 135-154. https://doi.org/10.1002/hrdq.3920100205.

Kumar, S. (2008). Role of leadership in knowledge management: A study. Journal of Knowledge Management, 12(4), 3-15. https://doi.org/10.1108/13673270810884219.

Lapointe, É., and Vandenberghe, C. (2018). Examination of the relationships between servant leadership, organizational commitment, and voice and antisocial behaviors. Journal of Business Ethics, 148: 99-115. https://doi.org/10.1007/s10551-015-3002-9.

Litz, D. (2011). Globalization and the changing face of educational leadership: Current trends \& emerging dilemmas. International Education Studies, 4(3), 47. https://doi.org/10.5539/ies.v4n3p47.

Mathieu, J.E., and Zajac, D.M. (1990). A review and meta-analysis of the antecedents, correlates, and consequences of organizational commitment. Psychological Bulletin, 108, 171-194. https://doi.org/10.1037/0033-2909.108.2.171.

Meyer, J.P., and Allen, N.J. (1990). The measurement and antecedents of affective, continuance and normative commitment to the organization. Journal of Occupational Psychology, 63, 1-18. https://doi.org/10.1111/j.2044-8325.1990.tb00506.x.

Meyer, J.P., and Allen, N.J. (1991). A three-component conceptualization of organizational commitment. Human Resource Management Review, 1, 61-89. https://doi.org/10.1016/1053-4822(91)90011-Z.

Meyer, J.P., Stanley, D.J., Herscovitch, L., and Topolnytsky, L. (2002). Affective, continuance, and normative commitment to the organization: A meta-analysis of antecedents, correlates, and consequences. Journal of Vocational Behavior, 61, 20-52. https://doi.org/10.1006/jvbe.2001.1842. 
Moser, K. (1997). Commitment in Organisationen. Zeitschrift für Arbeits- und Organisationspsychologie, 41, 160-170.

Moser, K., Soucek, R., and Hassel, A. (2014). Berufliche Entwicklung und organisationale Sozialisation. In: H. Schuler and U.P. Kanning (eds.), Lehrbuch der Personalpsychologie (3rd ed.), 449-500. Göttingen: Hogrefe.

Mowday, R.T., Porter, L.W., and Steers, R.M. (1982). Employee-organization linkages: The psychology of commitment, absenteeism, and turnover. New York: Academic Press. https://doi.org/10.1016/B978-0-12-509370-5.50005-8.

Mowday, R.T., Steers, RM., and Porter, L.W. (1979). The measurement of organizational commitment. Journal of Vocational Behavior, 14: 224-247. https://doi.org/10.1016/0001-8791(79)90072-1.

Nerdinger, F.W. (2019). Führung von Mitarbeitern. In: F.W. Nerdinger, G. Blickle, \& N. Schaper (Eds.), Arbeits- und Organisationspsychologie (4th ed.), 95-117. Berlin: Springer. https://doi.org/10.1007/978-3-662-56666-4_7.

Otte, M. (2006). Der Crash kommt: Die neue Weltwirtschaftskrise und wie Sie sich darauf vorbereiten. Berlin: Econ.

Pallant, J. (2013). SPSS survival manual: A step by step guide to data analysis using IBM SPSS (5th ed.). Maidenhead, Berkshire: McGraw Hill.

Podsakoff, P.M., MacKenzie, S.B., and Bommer, W.H. (1996). Transformational leader behaviors and substitutes for leadership as determinants of employee satisfaction, commitment, trust, and organizational citizenship behaviors. Journal of Management, 22, 259-298. https://doi.org/10.1177/014920639602200204.

Podsakoff, P.M., MacKenzie, S.B., Moorman, R.H., and Fetter, R. (1990). Transformational leader behaviors and their effects on followers' trust in leader, satisfaction, and organizational citizenship behaviors. The Leadership Quarterly, 1, 107-142. https://doi.org/10.1016/1048-9843(90)90009-7.

Raab-Steiner, E., and Benesch, M. (2015). Der Fragebogen: Von der Forschungsidee zur SPSS-Auswertung (4th ed.). Wien: Facultas.

Riketta, M., and van Dick, R. (2009). Commitment's place in the literature. In: H.J. Klein, T.E. Becker, and J.P. Meyer (eds.), Commitment in organizations: Accumulated wisdom and new directions: 69-95. New York: Routledge.

Sainger, G. (2018). Leadership in digital age: A study on the role of leader in this era of digital transformation. International Jounal on Leadership, 6(1), 1-6.

Salancik, G.R. (1977). Commitment and the control of organizational behavior and belief. In B. Staw and G. R. Salancik (eds.), New directions in organizational behavior: 1-54. Chicago: St. Clair Press.

Schmidt, K.-H., Hollmann, S., and Sodenkamp, D. (1998). Psychometrische Eigenschaft und Validität einer deutschen Fassung des „Commitment“ - Fragebogens von Allen und Meyer (1990). Zeitschrift für Differentielle und Diagnostische Psychologie, 19, 93-106.

Schuhmacher, F., and Geschwill, R. (2014). Employer Branding: Human Resources Management für die Unternehmensführung (2nd ed.). Wiesbaden: Springer Gabler.

https://doi.org/10.1007/978-3-8349-4631-7.

Solinger, O.N., van Olffen, W., and Roe, R.A. (2008). Beyond the three-component model of organizational commitment. Journal of Applied Psychology, 93, 70-83. https://doi.org/10.1037/0021-9010.93.1.70.

Sosik, J.J., and Jung, D.I. (2010). Full range leadership development: Pathways for people, profit, and planet. New York: Routledge. https://doi.org/10.4324/9780203843161.

Sow, M., and Aborbie, S. (2018). Impact of leadership on digital transformation. Business and Economic Research, 8(3), 139-148. https://doi.org/10.5296/ber.v8i3.13368. 
Sprenger, B., and Novotny, T. (2016). Der Weg aus dem Leadership Dilemma: Team-Exzellenz an der Spitze! Berlin: Springer. https://doi.org/10.1007/978-3-662-47147-0.

Tavakkoli, R. (2009). Arbeitgeberwettbewerbe und ihre Implikationen für Unternehmenskultur und Talent-Management. Wirtschaftspsychologie, 11(3), 31-41.

van Dick, R. (2004). Commitment und Identifikation mit Organisationen. Göttingen: Hogrefe.

Westphal, A., and Gmür, M. (2009). Organisationales Commitment und seine Einflussfaktoren: Eine qualitative Metaanalyse. Journal für Betriebswirtschaft, 59, 201-229. https://doi.org/10.1007/s11301-009-0054-x.

Zimmermann, K.F. (2007). Demographie, Migration und unternehmerische Personal Strategien. In: W. Ballwiese and C. Börsig (eds.), Demographischer Wandel als unternehmerische Herausforderung: Kongress-Dokumentation 60. Deutscher Betriebswirtschafter-Tag 2006, 11-22. Stuttgart: Schäffer-Poeschel. 